\title{
Chemical modulators of the innate immune response alter gypsy moth larval susceptibility to Bacillus thuringiensis
}

\author{
Nichole A Broderick1,2,3,4, Kenneth F Raffa1 and Jo Handelsman*2,3,5
}

\begin{abstract}
Background: The gut comprises an essential barrier that protects both invertebrate and vertebrate animals from invasion by microorganisms. Disruption of the balanced relationship between indigenous gut microbiota and their host can result in gut bacteria eliciting host responses similar to those caused by invasive pathogens. For example, ingestion of Bacillus thuringiensis by larvae of some species of susceptible Lepidoptera can result in normally benign enteric bacteria exerting pathogenic effects.

Results: We explored the potential role of the insect immune response in mortality caused by B. thuringiensis in conjunction with gut bacteria. Two lines of evidence support such a role. First, ingestion of $B$. thuringiensis by gypsy moth larvae led to the depletion of their hemocytes. Second, pharmacological agents that are known to modulate innate immune responses of invertebrates and vertebrates altered larval mortality induced by $B$. thuringiensis. Specifically, Gram-negative peptidoglycan pre-treated with lysozyme accelerated B. thuringiensis-induced killing of larvae previously made less susceptible due to treatment with antibiotics. Conversely, several inhibitors of the innate immune response (eicosanoid inhibitors and antioxidants) increased the host's survival time following ingestion of $B$. thuringiensis.

Conclusions: This study demonstrates that $B$. thuringiensis infection provokes changes in the cellular immune response of gypsy moth larvae. The effects of chemicals known to modulate the innate immune response of many invertebrates and vertebrates, including Lepidoptera, also indicate a role of this response in B. thuringiensis killing. Interactions among B. thuringiensis toxin, enteric bacteria, and aspects of the gypsy moth immune response may provide a novel model to decipher mechanisms of sepsis associated with bacteria of gut origin.
\end{abstract}

\section{Background}

The gut epithelium and its associated microorganisms provide an important barrier that protects animals from the external environment. This barrier serves both to prevent invasion by potential pathogens and limit the elicitation of host responses to the resident microbiota $[1,2]$. Dysfunction of this barrier, which can occur as a result of alterations of the normal gut ecology, impairment of host immune defenses, or physical disruption of intestinal epithelia, may lead to pathological states [3-6].

To breach the gut barrier, many enteric pathogens have evolved specific strategies such as production of toxins that physically disrupt cells of the gut epithelium [7-11].

\footnotetext{
* Correspondence: jo.handelsman@yale.edu

2 Department of Bacteriology, University of Wisconsin, Madison, WI 53706, USA Full list of author information is available at the end of the article
}

B. thuringiensis kills insects through the production of such toxins, designated insecticidal crystal proteins. Following ingestion of $B$. thuringiensis by susceptible larvae, these toxins initiate killing of insects through a multi-step process that includes the formation of pores and lysis of midgut epithelial cells [12-15]. Despite a detailed understanding of the mechanisms of toxin binding and disruption of the midgut epithelium, we know less about the subsequent events that cause larval mortality. Three mechanisms, which account for differences among host responses, have been suggested as the ultimate cause of larval death. The first, in which larvae die from toxin ingestion within hours or a day, is attributed to direct toxemia $[13,16,17]$. The second, in which prolonged feeding on $B$. thuringiensis leads to developmental arrest and eventual death is thought to occur by starvation [18-20]. 
The third, and most commonly cited mechanism is sepsis due to the growth of $B$. thuringiensis in the hemocoel following translocation of spores from the toxin-damaged gut into the hemolymph $[12,13,21,22]$. However, despite numerous reports of growth of $B$. thuringiensis in dead or moribund larvae [23-26], there is little evidence of $B$. thuringiensis proliferation in insect hemolymph prior to death. In addition, the proposed mechanism of death by $B$. thuringiensis bacteremia is not supported by the ability of cell-free preparations of toxin $[12,17,27]$, direct injection of some activated toxins into the hemocoel [28], or transgenic plant tissue producing the toxin [29] to kill larvae without the $B$. thuringiensis bacterium itself.

Previously, we demonstrated that $B$. thuringiensis toxin had substantially reduced ability to kill gypsy moth and three other species of lepidopteran larvae that had been treated with antibiotics, and that ingestion of an entericderived bacterium significantly increased lethality of subsequent ingestion of $B$. thuringiensis [30,31]. We observed that the enteric bacterium, Enterobacter sp. NAB3, grew to high population densities in vitro in hemolymph extracted from live gypsy moth larvae, whereas $B$. thuringiensis was rapidly cleared, which is inconsistent with the model of $B$. thuringiensis bacteremia as a cause of larval death. However, these results did not distinguish between the possibilities that gut bacteria contribute to $B$. thuringiensis-induced lethality by bacteremia or by another mechanism.

There is increasing recognition that an important feature of gut microbiota of both invertebrates and vertebrates is their ability to shape and modulate the host immune response [32-36]. In certain circumstances this effect can become deleterious to the host. For instance, uncontrolled activation of the immune response by enteric bacteria leads to chronic infection and pathogenesis in both invertebrates and vertebrates [37-39]. Interestingly, some recent studies have also linked activation of the immune response of Lepidoptera to ingestion of nonlethal doses of $B$. thuringiensis. For example, ingestion of low doses of B. thuringiensis by Galleria mellonella larvae increased both oxidative stress levels in the gut [40] and the phagocytic activity of hemocytes [41]. In Trichoplusia $n i$ larvae, exposure to $B$. thuringiensis reduced both the numbers of hemocytes and components of the humoral immune response (antimicrobial peptides and phenoloxidase activity) [42]. It remains unclear what effectors trigger this immune modulation, and the contribution of enteric bacteria to this response is not known. Modulation of the host immune response could be an indirect mechanism by which gut microbiota alter susceptibility to $B$. thuringiensis.

As an initial step to distinguish between a direct or host-mediated role of gut microbiota in larval death following the ingestion of $B$. thuringiensis, we examined the possible association between the host immune response and larval susceptibility to $B$. thuringiensis.

\section{Results}

Effects of intra-hemocoelic injection of $B$. thuringiensis and Enterobacter sp. NAB3 on larval hemolymph

Injections of greater than $10^{7}$ cells of an over-night culture of either B. thuringiensis or Enterobacter sp. NAB3 into the hemocoel of gypsy moth larvae led to a pronounced cellular and humoral immune response (Figure $1)$. In hemolymph sampled from larvae $24 \mathrm{~h}$ after injection of Enterobacter sp. NAB3, melanization of plasma and aggregation of hemocytes $[43,44]$ were evident (Figure 1b). Hemocyte aggregation was also observed in hemolymph samples from larvae injected with $B$. thuringiensis (Figure 1c), though these aggregates appeared smaller than aggregates from larvae injected with Enterobacter sp. NAB3. Hemocyte aggregation was not observed in hemolymph sampled from control larvae (Figure 1a).

\section{Effects of ingestion of B. thuringiensis on larval hemolymph and mortality}

We examined hemocytes and hemolymph in larvae containing enteric bacteria following oral ingestion of $B$. thuringiensis cells and toxin (Table 1). Microscopic examination of larval hemolymph revealed that the number of hemocytes declined following ingestion of $B$. thuringiensis. Defects in larval hemocytes were commonly observed within $14 \mathrm{~h}$ of ingestion of $B$. thuringiensis. This decrease in hemocyte abundance and appearance of defects occurred in advance of larval mortality. At $24 \mathrm{~h}$ post-ingestion of $B$. thuringiensis, larval mortality remained below $10 \%$, even though $75 \%$ of samples contained fewer hemocytes and hemocytes with abnormalities (Table 1). Hemocytes from control larvae displayed no abnormalities and no larval mortality was observed (Figure 2; see also additional file 1). The hemolymph of uninfected larvae contained hemocytes, predominantly plasmatocytes and granulocytes, which displayed no abnormal characteristics. Moreover, these plasmatocytes retained the ability to adhere to a glass surface and form pseudopodia (Figure 2, left panel and insets). The plasma of control larvae remained free of debris or discoloration in samples taken over the course of the assay period, and no bacteria were observed over the course of the assay. In contrast, hemocytes from larvae fed B. thuringiensis were greatly reduced in number, lacked adhesive properties, and contained refractive inclusions and signs of membrane disruption (Figure 2, center panel and insets). As the number of hemocytes decreased, the plasma darkened and granular material or debris accumulated in samples (Figure 2, center and right panels). The loss of nearly all hemocytes corresponded with the onset of lar- 


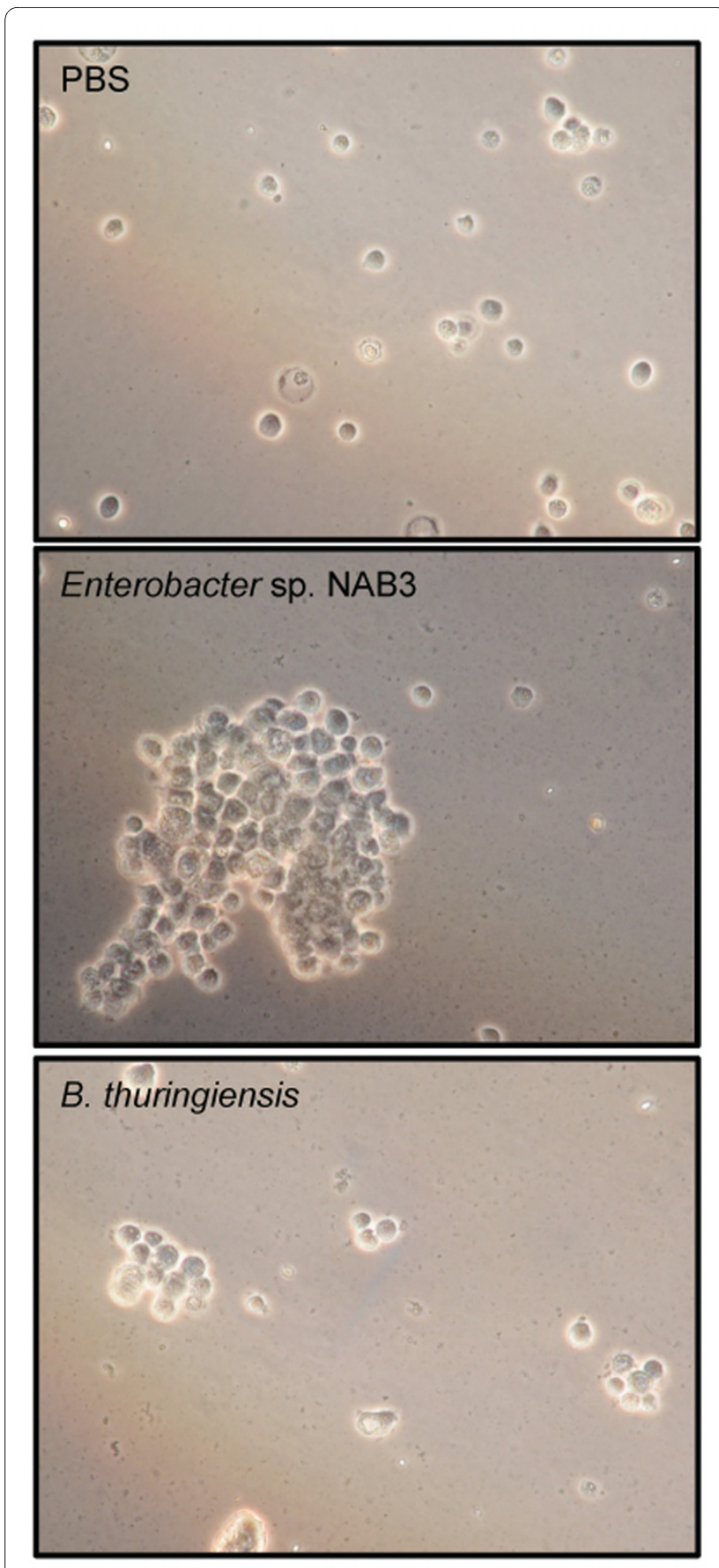

Figure 1 Effect of intra-hemocoelic injection of Enterobacter sp. NAB3 or B. thuringiensis cells on hemocytes of gypsy moth larvae. (a) $10 \mu \mathrm{l}$ of PBS, (b) approximately $10^{7}$ cells of Enterobacter sp. NAB3 or (c) B. thuringiensis (non-sporulated) were introduced into three sepa-

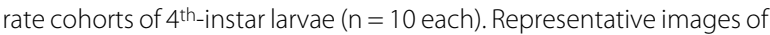
samples from each treatment are shown. To monitor the growth of injected bacteria, hemolymph samples were removed after $24 \mathrm{~h}$ and observed by light microscopy at 40x. Hemocytes from uninfected larvae were scattered randomly in the microscope field (a). In contrast, large aggregates of hemocytes were observed in samples from larvae injected with NAB3 (b) and smaller aggregates in samples from larvae injected with B. thuringiensis (c). val death (Table 1) and the appearance of $B$. thuringiensis cells in hemolymph samples (Figure 2, right panel and insets).

\section{Effects of bacterial components capable of eliciting immune responses on larval susceptibility to $B$. thuringiensis toxin}

Our observation that $B$. thuringiensis ingestion affected cellular immunity suggested the hypothesis that gut bacteria exert their effect on larval susceptibility to $B$. thuringiensis in part through stimulation of the host immune response. To determine whether bacterial cell components mediated $B$. thuringiensis-induced killing, we examined the effect of cell extracts known to trigger immune reactions in many invertebrate and vertebrate hosts, including Lepidoptera, [45-49] on gypsy moth susceptibility to $B$. thuringiensis. We examined the effect of commercial and purified lipopolysaccharide preparations and various peptidoglycan-derived compounds on larval mortality when co-administered with $B$. thuringiensis. As shown previously [30,31], rearing larvae on antibiotics reduced their susceptibility to $B$. thuringiensis (MVPII, $\mathrm{p}$ $=0.0202$; Dipel, $\mathrm{p}<0.0001$, Table 2), and Enterobacter sp. NAB3 accelerated mortality of larvae fed $B$. thuringiensis plus antibiotics in assays using either $B$. thuringiensis Cry1Ac toxin (MVPII) or viable B. thuringiensis cells and toxins (DiPel) (Figure 3, Table 2; see also additional files 2 and 3). Feeding peptidoglycan from Gram-negative bacteria, solubilized by pre-treatment with lysozyme, in combination with $B$. thuringiensis reduced time to death of antibiotic-reared larvae (Figure 3, Table 2). Regardless of the B. thuringiensis formulation, the lysozyme-treated peptidoglycan accelerated mortality of antibiotic-treated larvae, and the effect of the lysozyme-treated peptidoglycan was not significantly different from Enterobacter sp. NAB3 (Figure 3). Restoration of killing by peptidoglycan was not affected by the addition of lipopolysaccharide to either $B$. thuringiensis formulation. There was no effect of either crude (peptidoglycan-contaminated [50]) or purified lipopolysaccharide or non-lysozyme treated-polymeric peptidoglycan on larval mortality with $B$. thuringiensis in antibiotic-treated larvae. Ingestion of monomeric peptidoglycan (tracheal cytotoxin) significantly accelerated mortality of larvae reared on antibiotics and treated with the live cell formulation of $B$. thuringiensis (DiPel, Figure 3, Table 2), but not with $B$. thuringiensis toxin alone (MVPII, Table 2).

In the absence of antibiotics, larvae were highly susceptible to the live cell formulation of $\mathrm{B}$. thuringiensis and the addition of bacterial compounds had no effect on larval survival rates (Table 2). However, the addition of Enterobacter sp. NAB3 and peptidoglycan fragments derived from bacteria accelerated mortality caused by B. thuringiensis toxin alone (MVPII, Figure 3). Neither 
Table 1: Temporal sequence of effects of ingestion of a low dose of live cell formulation of B. thuringiensis (DiPel 10 IU) on condition of hemocytes and larval mortality in third-instar gypsy moth.

\begin{tabular}{|c|c|c|c|c|c|c|}
\hline \multirow[t]{2}{*}{ Time (h) } & \multicolumn{2}{|c|}{ Larvae with hemocyte abnormalitiesa (proportion) } & \multicolumn{2}{|c|}{ Hemocyte ratingb } & \multicolumn{2}{|c|}{ Larval mortality (proportion) } \\
\hline & No treatment & Bt & No treatment & Bt & No treatment & Bt \\
\hline 0 & 0.00 & 0.00 & +++ & +++ & 0.00 & 0.00 \\
\hline 14 & 0.00 & 0.40 & +++ & ++ & 0.00 & 0.02 \\
\hline 24 & 0.00 & 0.75 & +++ & + & 0.00 & 0.07 \\
\hline 32 & 0.00 & 0.87 & +++ & $+/-$ & 0.00 & 0.15 \\
\hline \multicolumn{7}{|c|}{$\begin{array}{l}\mathrm{a} n=5 \text { for each treatment. } \\
\mathrm{b} \text { Rating scale: } \\
+++ \text { hemocytes entire, adhesive properties } \\
++: \text { some hemocytes, inclusions present } \\
+: \text { very few hemocytes, ruptured cells } \\
-: \text { no hemocytes }\end{array}$} \\
\hline
\end{tabular}

preparation of lipopolysaccharide nor peptidoglycan that had not been treated with lysozyme affected mortality induced by the cell-free formulation of $\mathrm{B}$. thuringiensis toxin (MVPII, Table 2).

\section{Effect of eicosanoid inhibitors and antioxidants on larval} mortality associated with ingestion of $\mathrm{B}$. thuringiensis toxin To further test the hypothesis that larval susceptibility to $B$. thuringiensis toxin is modified by the host immune response to components of enteric bacteria, we fed larvae compounds previously demonstrated to inhibit the humoral and cellular immune responses of insects. Specifically, inhibitors of reactive oxygen and nitrogen species, phenoloxidase, and eicosanoid biosynthesis were fed to larvae to assess their effect on larval susceptibility to $B$. thuringiensis toxin. Five compounds, acetylsalicylic acid, indomethacin, glutathione, $\mathrm{N}$-acetyl cysteine, and $\mathrm{S}$ methyl-L-thiocitrulline, delayed mortality compared to larvae fed B. thuringiensis toxin alone. None of the compounds significantly affected final mortality and six had no effect on either the final mortality or survival time of larvae fed B. thuringiensis (Table 3).

Dose-response assays with acetylsalicylic acid, glutathione, piroxicam, and indomethacin demonstrated complex relationships between inhibitor concentration and larval survival (Figure 4; see also additional file 4). Acetylsalicylic acid extended larval survival in the presence of $B$. thuringiensis toxin, but only at the high concentration $(100 \mu \mathrm{g})$; the survival time of larvae treated with lower concentrations did not differ significantly from toxin alone. Most of the concentrations of indomethacin and glutathione that we tested increased larval survival time following ingestion of a lethal dose of $B$. thuringiensis toxin (Figure 4). Survival times of larvae treated with the highest concentrations of indomethacin and glutathione
(100 $\mu \mathrm{g}$ and $12 \mu \mathrm{g}$, respectively) did not differ significantly from those treated with toxin alone.

\section{Discussion}

Four lines of evidence indicate that the innate immune response is involved in $B$. thuringiensis-induced mortality of $L$. dispar. First, injections of $B$. thuringiensis and Enterobacter sp. NAB3 into the insect hemocoel were accompanied by melanization and hemocyte aggregation, both of which are indicators of an activated innate immune response. Second, as demonstrated here and reported by Ericsson et al. [42], depletion of hemocytes, the key actors of the cellular immune response of insects, was observed following $B$. thuringiensis ingestion in the absence of bacteremia. Third, fragments of peptidoglycan, an inducer of innate immunity, substituted for Enterobacter in accelerating killing of antibiotic-treated larvae with B. thuringiensis. Fourth, antioxidants and compounds that inhibit eicosanoid biosynthesis, and thereby suppress the innate immune response, delayed B. thuringiensis-induced mortality.

Based on these results, we propose the hypothesis that $B$. thuringiensis incites an overblown innate immune response, in cooperation with other factors, which in turn contributes to host death. This immune induction either requires the normal gut microbiota or is directly suppressed by antibiotic treatment, and is restored to antibiotic-treated larvae by addition of bacteria or immunostimulatory cell fragments. This model is derived, in part, from the mechanism of mammalian sepsis in which gut-derived microbiota serve as both sources of infectious bacteria and modulators of the innate immune system [51-54]. Germ-free mammals are less susceptible to sepsis, just as gypsy moth larvae lacking enteric bacteria are less susceptible to $B$. thuringiensis 


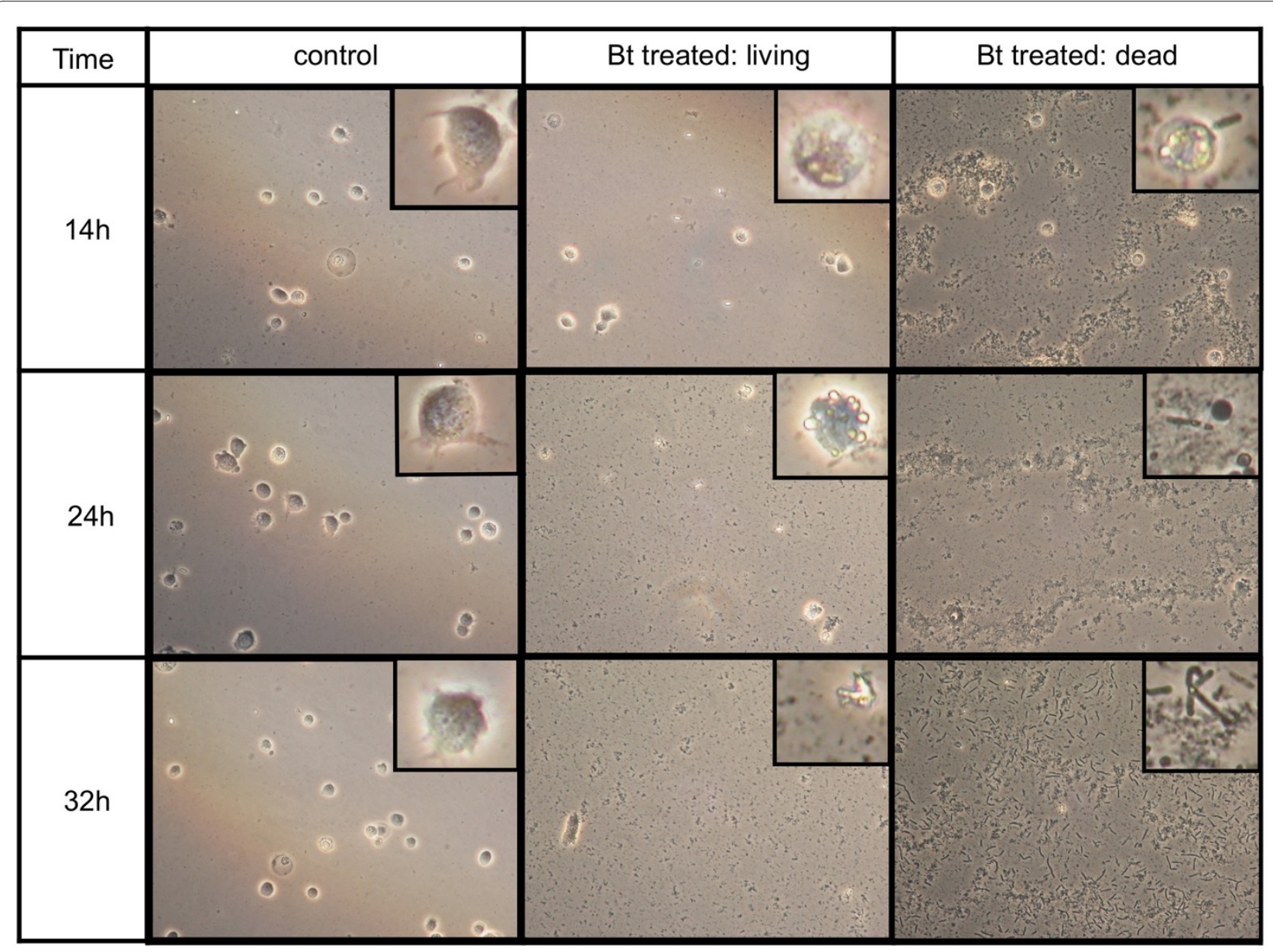

Figure 2 Effect of ingestion of $\boldsymbol{B}$. thuringiensis (DiPel $\mathbf{5 0}$ IU) on larval hemocytes. Third-instar gypsy moth larvae were fed either distilled water or $50 \mathrm{IU}$ of DiPel $(n=50)$. Hemolymph was sampled from a separate cohort of five larvae of each treatment at $0,14,24$, and $32 \mathrm{~h}$ post-infection and examined by light microscopy (40X). Representative images are shown, including magnification of individual hemocytes (inset). No differences were observed among larvae from different treatments at $0 \mathrm{~h}$ (Additional file 1). Hemocytes from control larvae are adherent and emit pseudopodia (left panel). In contrast, hemocytes from larvae that ingested B. thuringiensis are non-adherent and contain inclusions (center panel). At the time points sampled, the majority of larvae fed B. thuringiensis were still alive. When present, dead larvae that had been fed B. thuringiensis were also sampled (right panel). In dead larvae, only a few abnormal hemocytes were detected and B. thuringiensis cells were present (right panel, insets). No mortality was observed in the controls that were not fed $B$. thuringiensis. Mortality values of control and $B$. thuringiensis-treated larvae corresponding to each time point are shown in Table 1.

[53,55-57]. Further support for our model can be derived from recent work demonstrating that ingestion of nonpathogenic bacteria can induce the immune response of lepidopteran larvae [58]. This suggests that the microbiota are capable of altering the immune status of larvae without crossing the gut epithelium and could thus influence the host response to pathogenic bacteria. Additionally, Ericsson et al. [42] reported that reductions in the larval immune response following ingestion of a low dose of $B$. thuringiensis correlated with lower susceptibility to subsequent ingestion of $B$. thuringiensis. Taken together, these data provide support for the hypothesis that the host innate immune response contributes to pathogenesis and killing by $B$. thuringiensis.
We cannot rule out other factors that might co-vary with innate immunity. Many pharmaceutical inhibitors have non-specific effects on animals that may confound interpretation of the results [59-61]. While eicosanoids mediate various cellular reactions responsible for clearing bacterial infections from hemolymph circulation and are induced in Lepidoptera in response to bacterial challenge [62-64], they also have other physiological functions including ion transport and reproduction $[60,65]$. Thus, it is possible that the compounds we used have a direct effect on the health of the insect gut or affect another cellular process that, in turn, influences larval susceptibility to $B$. thuringiensis. Nevertheless, it is notable that we observed significantly delayed mortality with the antioxidant glutathione and in the presence of diverse com- 
Table 2: Effects of bacterial cell-derived immune elicitors on susceptibility of third-instar gypsy moth larvae reared without enteric bacteria (antibiotics) or with enteric bacteria (no antibiotics) to B. thuringiensis (Bt).

a) Bt cell preparation (DiPel, 50 IU)

\begin{tabular}{|c|c|c|c|}
\hline Rearing treatment & Elicitor added to $B$. thuringiensis & $\begin{array}{l}\text { Reared without antibiotics } \\
\text { Bt alone }\end{array}$ & $\begin{array}{c}\text { Reared with antibiotics } \\
\text { Bt alone }\end{array}$ \\
\hline No Antibiotics & Bt alone & -- & $<0.0001$ \\
\hline No Antibiotics & Enterobacter sp. NAB3 & 0.6882 & $<0.0001$ \\
\hline Antibiotics & Enterobacter sp. NAB3 & 0.0956 & $<0.0001$ \\
\hline No Antibiotics & Crude lipopolysaccharide & 0.8231 & $<0.0001$ \\
\hline Antibiotics & Crude lipopolysaccharide & 0.0001 & 0.4942 \\
\hline No Antibiotics & Purified lipopolysaccharide & 0.7268 & $<0.0001$ \\
\hline Antibiotics & Purified lipopolysaccharide & $<0.0001$ & 0.5731 \\
\hline No Antibiotics & Bacillus cereus peptidoglycan & 0.0582 & 0.0100 \\
\hline Antibiotics & Bacillus cereus peptidoglycan & 0.0065 & 0.7331 \\
\hline No Antibiotics & Vibrio fisheri peptidoglycan & 0.1092 & $<0.0001$ \\
\hline Antibiotics & Vibrio fisheri peptidoglycan & 0.0010 & 0.1276 \\
\hline No Antibiotics & Tracheal cytotoxin & 0.0539 & $<0.0001$ \\
\hline Antibiotics & Tracheal cytotoxin & 0.4070 & $<0.0001$ \\
\hline No Antibiotics & $\begin{array}{l}\text { Lysozyme-digested } V \text {. fisheri } \\
\text { peptidoglycan }\end{array}$ & 0.2622 & $<0.0001$ \\
\hline Antibiotics & $\begin{array}{l}\text { Lysozyme-digested } V \text {. fisheri } \\
\text { peptidoglycan }\end{array}$ & 0.2356 & $<0.0001$ \\
\hline No Antibiotics & $\begin{array}{l}\text { Lysozyme-digested } V \text {. fisheri } \\
\text { peptidoglycan }+ \text { purified } \\
\text { lipopolysaccharide }\end{array}$ & 0.1120 & $<0.0001$ \\
\hline Antibiotics & $\begin{array}{l}\text { Lysozyme-digested V. fisheri } \\
\text { peptidoglycan + purified } \\
\text { lipopolysaccharide }\end{array}$ & 0.2328 & 0.0002 \\
\hline
\end{tabular}

b) Bt Cry1 Ac toxin (MVPII, 20 ug)

Reared without antibiotics

Reared with antibiotics

\begin{tabular}{|c|c|c|c|}
\hline Rearing treatment & Elicitor added to $\mathrm{B}$. thuringiensis & Bt alone & Bt alone \\
\hline No Antibiotics & Bt alone & -- & 0.0202 \\
\hline No Antibiotics & Enterobacter sp. NAB3 & $<0.0001$ & $<0.0001$ \\
\hline Antibiotics & Enterobacter sp. NAB3 & 0.7182 & 0.0002 \\
\hline No Antibiotics & Crude lipopolysaccharide & 0.6689 & 0.0919 \\
\hline Antibiotics & Crude lipopolysaccharide & 0.0440 & 0.8517 \\
\hline No Antibiotics & Purified lipopolysaccharide & 0.8138 & 0.0038 \\
\hline Antibiotics & Purified lipopolysaccharide & 0.0456 & 0.5915 \\
\hline No Antibiotics & Bacillus cereus peptidoglycan & 0.0651 & $<0.0001$ \\
\hline Antibiotics & Bacillus cereus peptidoglycan & 0.0264 & 0.1951 \\
\hline No Antibiotics & Vibrio fisheri peptidoglycan & 0.5111 & 0.0056 \\
\hline Antibiotics & Vibrio fisheri peptidoglycan & 0.0196 & 0.8623 \\
\hline No Antibiotics & Tracheal cytotoxin & 0.9977 & 0.0116 \\
\hline
\end{tabular}


Table 2: Effects of bacterial cell-derived immune elicitors on susceptibility of third-instar gypsy moth larvae reared without enteric bacteria (antibiotics) or with enteric bacteria (no antibiotics) to B. thuringiensis (Bt). (Continued)

\begin{tabular}{|c|c|c|c|}
\hline Antibiotics & Tracheal cytotoxin & 0.0188 & 0.8914 \\
\hline No Antibiotics & $\begin{array}{l}\text { Lysozyme-digested } V \text {. fisheri } \\
\text { peptidoglycan }\end{array}$ & $<0.0001$ & $<0.0001$ \\
\hline Antibiotics & $\begin{array}{l}\text { Lysozyme-digested } V \text {. fisheri } \\
\text { peptidoglycan }\end{array}$ & 0.7613 & 0.0001 \\
\hline No Antibiotics & $\begin{array}{l}\text { Lysozyme-digested } V \text {. fisheri } \\
\text { peptidoglycan + purified } \\
\text { lipopolysaccharide }\end{array}$ & 0.0005 & $<0.0001$ \\
\hline Antibiotics & $\begin{array}{l}\text { Lysozyme-digested } V \text {. fisheri } \\
\text { peptidoglycan }+ \text { purified } \\
\text { lipopolysaccharide }\end{array}$ & 0.5645 & $<0.0001$ \\
\hline
\end{tabular}

Two formulations of $B$. thuringiensis, DiPel 50 IU (a) and MVPII $20 \mu \mathrm{g}(\mathrm{b})$, were assayed. The significance (p-values) of the log-rank test comparing larval mortality of each experimental treatment group to Bt alone or Bt alone when reared with antibiotics is shown.

pounds that suppress the synthesis of eicosanoids. The immune-suppressive compounds inhibit a variety of enzymes in eicosanoid biosynthesis, and all delay killing by $B$. thuringiensis, reducing the probability that the biological effects are due to a secondary activity of the pharmaceuticals. Moreover, peptidoglycan fragments, which induce the innate immune response, caused more rapid mortality in insects that had been treated with antibiotics.

Similarly, there is growing evidence that diverse classes of antibiotics, including the four used in this study, have immunomodulatory effects in addition to their antimicrobial activity [66]. While the immunomodulatory mechanisms of antibiotics are not fully understood, there is evidence that some directly reduce the host immune response, whereas others limit the release of immuneinducing bacterial components [67]. Further experiments are needed to fully differentiate the extents to which the reduction in susceptibility to $B$. thuringiensis when larvae are reared on antibiotics is due to the absence of gut bacteria or an immuno-suppressive effect of antibiotics. In the latter case, the re-introduction of bacteria, such as Enterobacter sp. NAB3, would likely stimulate the host immune response, and thus our current results do not permit us to separate these two possibilities. In either case, an immunomodulatory effect of antibiotics would further support a contribution of the host immune response in larval susceptibility to $B$. thuringiensis.

This is the third study, each with a different lepidopteran species, to report that ingestion of $B$. thuringiensis leads to alterations in hemocytes [41,42]. It remains unclear, however, whether the observed changes in hemocytes directly contribute to larval mortality or if they merely reflect changes in immune status. Interestingly, Ericsson et al. [42] reported that T. ni larvae resistant to $B$. thuringiensis had significantly fewer hemocytes than did susceptible larvae. Further experiments are needed to determine whether hemocytes are functionally required in susceptibility. Such experiments should include a comparison of the effect of ingestion of $B$. thuringiensis on hemocytes between larvae with and without enteric bacteria. In addition, while our work shows that immunogenic peptidoglycan fragments can restore $B$. thuringiensis susceptibility in larvae lacking gut bacteria, we do not know whether co-ingestion of peptidoglycan and $B$. thuringiensis leads to changes in hemocytes, nor have we identified the final immune effectors of $B$. thuringiensis-induced killing. However, the delayed mortality of larvae fed $B$. thuringiensis in combination with some antioxidants and eicosanoid inhibitors suggests that production of reactive oxygen species could be involved. Interestingly, hemocytes have been shown to be key regulators of the oxidative burst upon infection, particularly by promoting activation of the phenoloxidase cascade $[68,69]$, which might be caused by hemocyte rupture $[70,71]$.

The parallels between the progression of disease and mortality caused by $B$. thuringiensis with that in mammalian sepsis are noteworthy. Disease and death associated with mammalian sepsis are believed to be caused by uncontrolled host production of local immune mediators leading to local and systemic inflammatory responses $[52,72,73]$. Peptidoglycan induces the innate immune system of both invertebrates and vertebrates [45-49] and contributes to both sepsis and B. thuringiensis-induced killing in gypsy moth larvae. Eicosanoids and reactive oxygen and nitrogen species are critical in the innate immune response in mammals and treatments for sepsis often target these compounds [59,74-77]. In gypsy moth larvae, inhibitors of eicosanoid biosynthesis and antioxidants prevent or slow disease progress, suggesting a role of innate immunity.

There is increasing evidence that diseases of animals are frequently caused by multiple microbial species. 


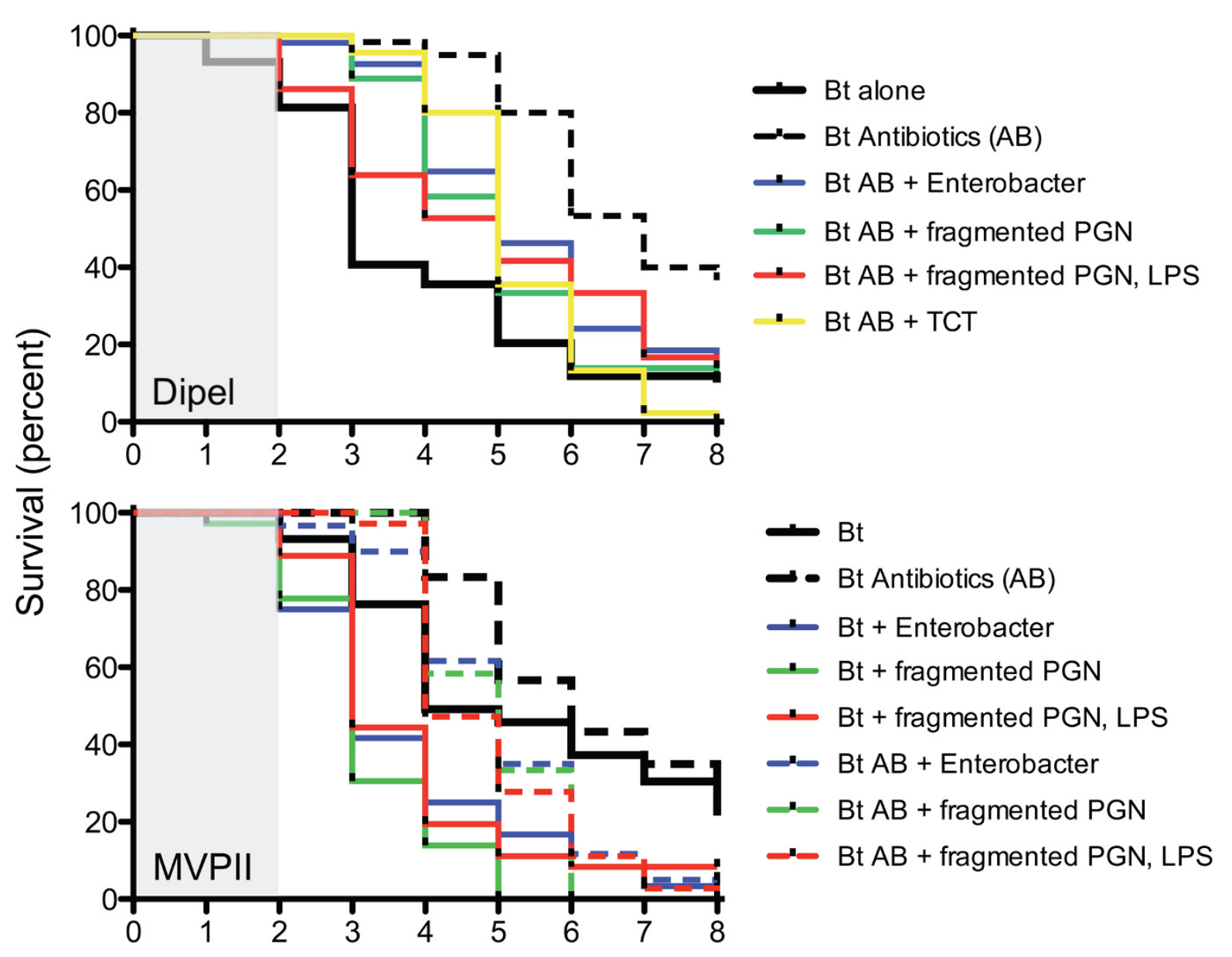

\section{Days post-ingestion}

Figure 3 Survival of third-instar gypsy moth larvae reared without enteric bacteria (antibiotics) or with enteric bacteria (no antibiotics) fed bacterial cell-derived compounds and B. thuringiensis (Bt). Two formulations of B. thuringiensis, DiPel 50 IU (upper) and MVPII $20 \mu \mathrm{g}$ (lower), were assayed. All experimental treatments were provided on artificial diet without antibiotics, gray shading indicates days on which larvae received treatments. The effects of the compounds were assessed in comparison to B. thuringiensis toxin and significance of treatments was determined using the log-rank analysis of PROC LIFETEST (SAS 9.1, Table 2, Additional file 2). Treatments with a survival distribution function that differ significantly from $B$. thuringiensis toxin alone $(p<0.05)$ are shown; $p$-values of all treatments are presented in Table 2 . Three independent cohorts of larvae were assayed. No mortality was observed when larvae were fed the compounds alone (Additional file 3).

These polymicrobial infections often include members of the indigenous microbiota and lead to complex interactions with the host immune system [74]. Using Drosophila as a model of cystic fibrosis, Sibley et al. [78] demonstrated that pathogenicity depends on synergy between Pseudomonas aeruginosa and members of the oropharyngeal microbiota. Even in the absence of infection changes in the gut immune response can lead to pathogenic states associated with an imbalance in composition of the gut microbiota [32].

Our results are consistent with the hypothesis that the effect of gut bacteria on host killing following ingestion of B. thuringiensis in antibiotic-treated larvae is mediated by the innate immune response. Further experiments, including direct monitoring of the immune response of larvae, are needed to identify the specific defense responses induced following ingestion of $B$. thuringiensis and the impact of antibiotic treatment and enteric bacteria on these events.

\section{Conclusion}

We demonstrate that larvae fed $B$. thuringiensis die prior to observable growth of bacteria in the hemolymph. An immuno-stimulatory compound, fragments of Gramnegative peptidoglycan, confers $B$. thuringiensis toxininduced killing in the absence of indigenous enteric bac- 
Table 3: Effect of immune inhibitors on susceptibility of third-instar gypsy moth larvae reared without antibiotics to $B$. thuringiensis toxin (MVPIl; $20 \mu \mathrm{g}$ ).

\begin{tabular}{|c|c|c|c|c|c|c|}
\hline \multirow[b]{2}{*}{$\begin{array}{l}\text { Compound added to } \\
\text { B. thuringiensis toxin } \\
\text { (MVPII) }\end{array}$} & \multirow[b]{2}{*}{ Compound activity } & \multirow[b]{2}{*}{$\begin{array}{l}\text { Compound } \\
\text { concentration }\end{array}$} & \multicolumn{3}{|c|}{ Total Mortality (mean proportion \pm SE) } & \multirow[b]{2}{*}{$\begin{array}{l}\text { Significance } \\
\text { (p-value) of } \\
\text { rank analysis }\end{array}$} \\
\hline & & & $\mathbf{N}$ & $\begin{array}{l}\text { without } \\
\text { B. thuringiensis }\end{array}$ & $\begin{array}{l}\text { with } \\
\text { B. thuringiensis }\end{array}$ & \\
\hline $\begin{array}{l}\text { B. thuringiensis toxin } \\
\text { control }\end{array}$ & & & 48 & $0.06 \pm 0.02$ & $0.92 \pm 0.15 a$ & \\
\hline Acetylsalicylic acid & Eicosanoid inhibitor (COX) & $100 \mu \mathrm{g}$ & 36 & $0.00 \pm 0.00$ & $0.81 \pm 0.16 \mathrm{ab}$ & 0.0396 \\
\hline Dexamethasone & Eicosanoid inhibitor $\left(\mathrm{PLA}_{2}\right)$ & $100 \mu \mathrm{g}$ & 24 & $0.00 \pm 0.00$ & $0.79 \pm 0.19 \mathrm{ab}$ & 0.4519 \\
\hline Indomethacin & Eicosanoid inhibitor (COX) & $10 \mu \mathrm{g}$ & 48 & $0.04 \pm 0.04$ & $0.83 \pm 0.14 a b$ & 0.0056 \\
\hline Esculetin & Eicosanoid inhibitor (LOX) & $100 \mu \mathrm{g}$ & 24 & $0.00 \pm 0.00$ & $0.83 \pm 0.18 \mathrm{ab}$ & 0.9757 \\
\hline Piroxicam & Eicosanoid inhibitor (COX) & $100 \mu \mathrm{g}$ & 36 & $0.04 \pm 0.02$ & $0.94 \pm 0.18 a$ & 0.2417 \\
\hline $\mathrm{N}$-acetyl cysteine & $\begin{array}{l}\text { Reactive oxygen } \\
\text { scavenger }\end{array}$ & $100 \mathrm{mM}$ & 36 & $0.03 \pm 0.01$ & $0.86 \pm 0.15 a$ & 0.0286 \\
\hline Phenylthiourea & $\begin{array}{l}\text { Nitric oxide scavenger, } \\
\text { phenoloxidase inhibitor }\end{array}$ & $75 \mathrm{mM}$ & 36 & $0.03 \pm 0.03$ & $0.81 \pm 0.15 a b$ & 0.3382 \\
\hline S-methyl-L-thiocitrulline & Nitric oxide scavenger & $100 \mathrm{mM}$ & 36 & $0.03 \pm 0.02$ & $0.83 \pm 0.15 \mathrm{ab}$ & 0.0245 \\
\hline Tannic acid & Phenoloxidase inhibitor & $100 \mu \mathrm{g}$ & 24 & $0.00 \pm 0.00$ & $0.79 \pm 0.19 a b$ & 0.2740 \\
\hline $\begin{array}{l}\text { S-nitroso-N-acetyl-I, I- } \\
\text { penicillamine }\end{array}$ & Nitric oxide donor & $100 \mathrm{mM}$ & 36 & $0.00 \pm 0.00$ & $0.94 \pm 0.18 a$ & 0.4409 \\
\hline
\end{tabular}

teria. Conversely, inhibitors of the innate immune response delay mortality of larvae following ingestion of B. thuringiensis toxin. We propose the hypothesis that the resident gut bacteria in gypsy moth larvae induce an innate immune response that contributes to $B$. thuringiensis toxin-induced killing, suggesting a parallel with mammalian sepsis in which gut bacteria contribute to an overblown innate immune response that is ultimately lethal to the host.

\section{Methods}

\section{Insects and rearing conditions}

Eggs of $L$. dispar were obtained from USDA-APHIS. All eggs were surface sterilized with a solution of Tween 80 (polyoxyethylene sorbitan monooleate), bleach, and distilled water as previously described [79]. Larvae were reared in $15-\mathrm{mm}$ Petri dishes on sterilized artificial diet (USDA, Hamden Formula) or sterilized artificial diet amended with antibiotics $(500 \mathrm{mg} / \mathrm{L}$ of diet each penicillin, gentamicin, rifampicin, streptomycin). Larvae were reared under 16:8 (L:D) photoperiod at $25^{\circ} \mathrm{C}$.

\section{Bacterial products and chemicals}

Two commercial formulations of B. thuringiensis, alone and in combination with various bacterial products and compounds, were used in assays. The DiPel ${ }^{\circ} \mathrm{TD}$ formulation consisted of cells, toxins (Cry1Aa, Cry1Ab, Cry1Ac, and Cry2A), and spores of B. thuringiensis subsp. kurstaki (Valent Biosciences, Libertyville, IL, USA). The MVPII formulation (DOW Agrosciences, San Diego, CA, USA) is comprised of Cry1Ac toxin encapsulated in NaCl-killed Pseudomonas fluorescens. Enterobacter sp. NAB3, a strain originally isolated from the midguts of gypsy moth larvae feeding on sterile artificial diet [80], was grown with shaking overnight in $1 / 2$-strength tryptic soy broth at $28^{\circ} \mathrm{C}$. The overnight culture was washed once and resuspended in $1 \times \mathrm{PBS}\left(10^{6} \mathrm{cells} / \mu \mathrm{l}\right)$ prior to use in assays.

Lysozyme and lipopolysaccharide from Escherichia coli 0111:B4 were obtained from commercial sources (SigmaAldrich, St. Louis, MO). Peptidoglycan-free purified $E$. coli lipopolysaccharide, polymeric diaminopimelic (DAP)-type peptidoglycan from Vibrio fisheri, and monomeric DAP-type peptidoglycan, also called tracheal cytotoxin, from Bordetella pertussis were kindly provided by the laboratories of William E. Goldman and Margaret J. McFall-Ngai. Peptidoglycan from Bacillus cereus was provided by S. Brook Peterson [81]. The following chemicals were obtained from Sigma-Aldrich, St. Louis, MO: acetylsalicylic acid, dexamethasone, esculetin, glutathione, indomethacin, $\mathrm{N}$-acetyl-cysteine, phenylthiourea, 


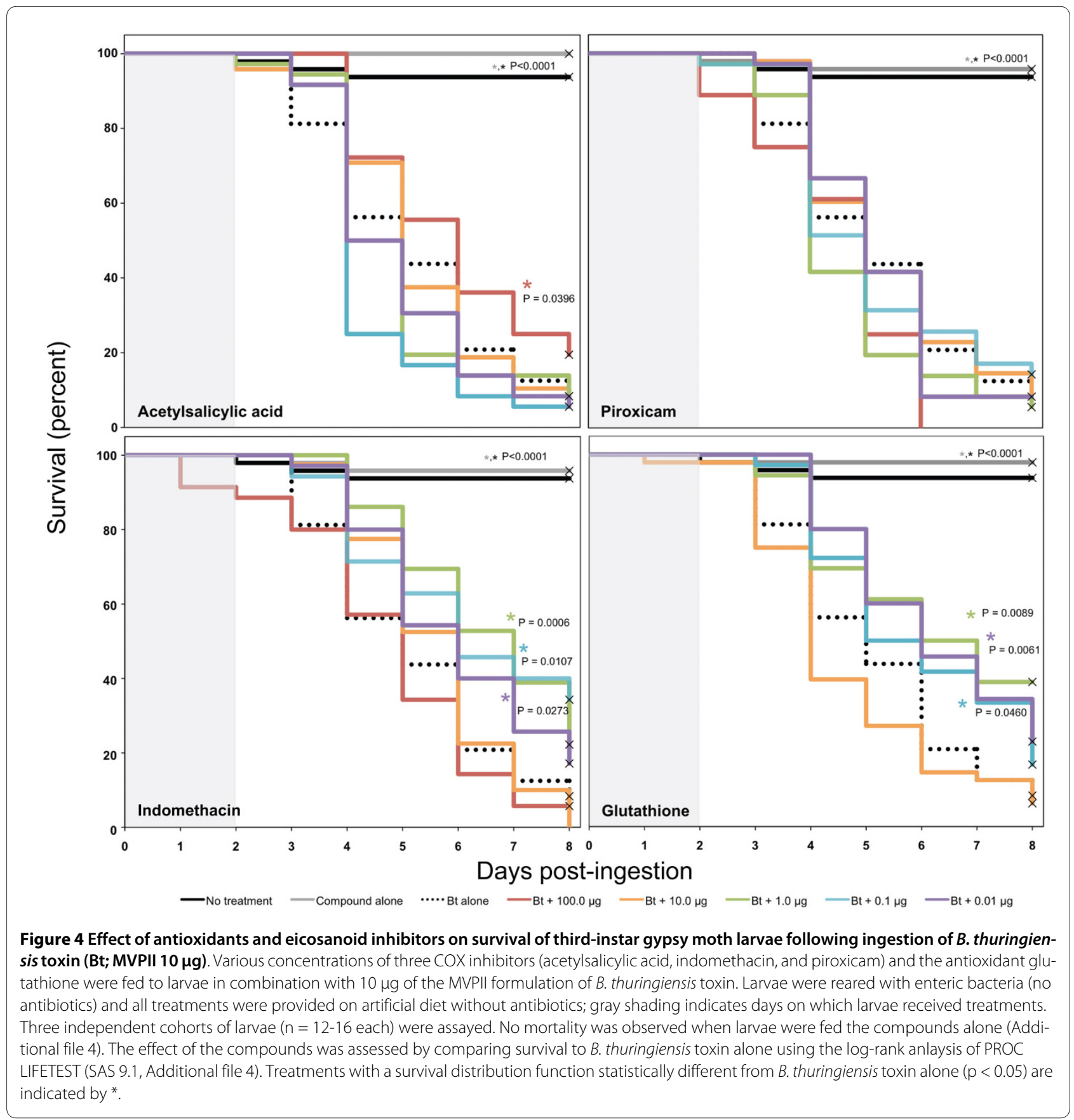

piroxicam, S-methyl-L-thiocitrulline, tannic acid, Snitroso-N-acetyl-I, I-penicillamine.

\section{Intra-hemocoelic injections and hemolymph sampling}

Fourth instar larvae were anesthetized by chilling on ice for $15 \mathrm{~min}$, then surface sterilized with 95\% ethanol $(\mathrm{EtOH})$. Injections were performed with a $20-\mu \mathrm{l}$ fixedvolume pipette and a snipped $200-\mu$ l pipette tip fitted with a 27-gauge needle. The syringe needle was inserted into the ventral abdomen between the first and second pair of prolegs, keeping the needle parallel to the body wall to avoid injuring the alimentary canal. Control larvae were injected with $10 \mu \mathrm{l}$ of phosphate buffered saline (PBS). Experimental larvae were injected with $10 \mu \mathrm{l}$ of a washed culture of Enterobacter sp. NAB3 or B. thuringiensis subsp. kurstaki adjusted to a concentration of $10^{6}$ cells/ $\mu$ l. Larvae were maintained in $15 \mathrm{~mm}$ Petri plates by treatment group $(\mathrm{n}=10)$ and provided with unamended sterile artificial diet for the duration of the assay. Hemolymph samples from larvae of each treatment were examined for bacteria $24 \mathrm{~h}$ after injection. Hemolymph was collected by piercing the last abdominal proleg with a $27-$ 
gauge needle and collecting the hemolymph drops with a $10-\mu \mathrm{l}$ fixed-volume pipette. Approximately $10 \mu \mathrm{l}$ of hemolymph was collected individually from five larvae for each treatment and diluted in PBS, $10 \mu \mathrm{l}$ of which was spotted onto a plate of 1/10-strength tryptic soy agar, while the other $10 \mu \mathrm{l}$ was placed on a glass slide for immediate microscopic observation.

Temporal monitoring of hemolymph following ingestion of B. thuringiensis toxin

B. thuringiensis mortality assays were performed as previously described [30]. All assays were performed on newly molted third-instar larvae using sterile artificial diet without antibiotics. Either sterile water or $50 \mathrm{IU}$ of DiPel was applied in a volume of $1 \mu \mathrm{l}$ to a standard diet disk (3-mm diameter, 1-mm height) and fed to larvae. Hemolymph samples were collected as described above for microscopy from five control larvae and five $B$. thuringiensistreated larvae at $14,18,24$, and $32 \mathrm{~h}$ after treatment. Additionally, hemolymph samples from 5 larvae were examined at the commencement of treatment $(0 \mathrm{~h})$. Additionally, mortality was monitored in a parallel cohort of larvae for the duration of the assay.

\section{Feeding assays with immune elicitors}

The effects of bacterial elicitors of the immune response of invertebrates and vertebrates on mortality following ingestion of $B$. thuringiensis were compared in larvae with indigenous gut bacteria (reared on unamended sterile diet) and axenic larvae (reared on diet amended with antibiotics) using two formulations of $B$. thuringiensis, MVPII and DiPel. All treatments were applied in 1- $\mu \mathrm{l}$ doses to a standard diet disk and fed to third-instar larvae on two consecutive days, at sample sizes shown in Table 2. All elicitors were tested alone to assess direct toxicity. Lysozyme-treated DAP-type peptidoglycan was prepared by incubating $5 \mathrm{mg} / \mathrm{ml}$ peptidoglycan in 1\% lysozyme [ 5 $\mathrm{mg} / \mathrm{ml}$ lysozyme in $0.1 \mathrm{M}$ sodium acetate buffer ( $\mathrm{pH}$ 5.0)] for $20 \mathrm{~min}$, followed by heating the mixture at $95^{\circ} \mathrm{C}$ for 5 min to inactivate lysozyme.

\section{Feeding assays with eicosanoid inhibitors and antioxidants} The effects of eicosanoid inhibitors and antioxidants on mortality resulting from ingestion of the MVPII formulation of $B$. thuringiensis were assayed in larvae reared on unamended sterile artificial diet. Each compound was fed alone and in combination with MVPII for two days as described above and mortality was recorded daily for 9 days, at sample sizes indicated in Table 3. Subsequently, a dose-response for four of the inhibitors, acetylsalicylic acid, indomethacin, glutathione, and piroxicam, was established using the same protocol.

\section{Statistical analysis}

Mean larval mortality and standard error were determined with data from either three or four replications of 10 to 12 larvae each using PROC MEANS [82]. Means were separated using Fisher's LSD at $\mathrm{P}=0.05$. The effect of bacterial elicitors or chemical inhibitors on time to death of $B$. thuringiensis treated larvae was analyzed using PROC LIFETEST [82]. Median survival times and their standard errors were obtained using the KaplanMeier estimation and rank analysis of PROC LIFETEST [82]. Survival curves of larvae fed B. thuringiensis toxin and various concentrations of acetylsalicylic acid, indomethacin, glutathione, and piroxicam were compared to $B$. thuringiensis toxin alone using the rank analysis of PROC LIFETEST [82].

\section{Additional material}

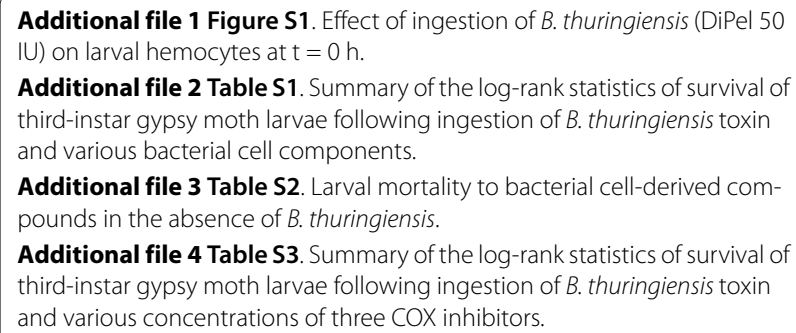

Additional file $\mathbf{2}$ Table S1. Summary of the log-rank statistics of survival of third-instar gypsy moth larvae following ingestion of $B$. thuringiensis toxin and various bacterial cell components.

Additional file $\mathbf{3}$ Table S2. Larval mortality to bacterial cell-derived compounds in the absence of $B$. thuringiensis.

Additional file $\mathbf{4}$ Table S3. Summary of the log-rank statistics of survival of third-instar gypsy moth larvae following ingestion of B. thuringiensis toxin and various concentrations of three COX inhibitors.

\section{Authors' contributions}

NAB performed all experiments. NAB and KFR performed the statistical analysis of the data. $N A B, J H$, and KFR conceived of and designed the study. $N A B, J H$ and KFR analyzed the data and wrote the manuscript. All authors approve the final manuscript.

\section{Acknowledgements}

We thank John Tanner (USDA-APHIS) for providing eggs of L. dispar, William E. Goldman (Washington University, St. Louis, MO) for purified lipopolysaccharide and tracheal cytotoxin and Josh Troll and Margaret McFall-Ngai (University of Wisconsin, Madison, WI) for purified V. fisheri peptidoglycan and helpful experimental advice. We thank Peter Crump (University of Wisconsin-Madison) for statistical assistance and Nicolas Buchon (EPFL, Lausanne, Switzerland), Susan Paskewitz (University of Wisconsin, Madison, WI) and two anonymous reviewers for helpful comments on earlier drafts of this manuscript. This work was supported by Hatch grant (\#5240) from the University of Wisconsin-Madison College of Agricultural and Life Sciences.

\section{Author Details}

1Department of Entomology, University of Wisconsin, Madison, WI 53706, USA, 2Department of Bacteriology, University of Wisconsin, Madison, WI 53706, USA, 3Department of Plant Pathology University of Wisconsin, Madison, WI 53706, USA, ${ }^{4}$ Current address: Global Health Institute, EPFL, Lausanne, 1004, Switzerland and ${ }^{5}$ Current address: Department of Molecular, Cellular and Developmental Biology, Yale University, New Haven, CT 06520, USA

Received: 12 June 2009 Accepted: 27 April 2010 Published: 27 April 2010

\section{References}

1. Artis D: Epithelial-cell recognition of commensal bacteria and maintenance of immune homeostasis in the gut. Nat Rev Immunol 2008, 8:411-420 
2. McCracken VJ, Lorenz RG: The gastrointestinal ecosystem: a precarious alliance among epithelium, immunity and microbiota. Cell Microbiol 2001, 3:1-11.

3. Collier-Hyams LS, Neish AS: Innate immune relationship between commensal flora and the mammalian intestinal epithelium. Cell Mol Life Sci 2005, 62:1339-1348.

4. Sansonetti PJ: War and peace at mucosal surfaces. Nat Rev Immunol 2004, 4:953-964.

5. Müller CA, Autenrieth IB, Peschel A: Innate defenses of the intestinal epithelial barrier. Cell Mol Life Sci 2005, 62:1297-1307.

6. Stecher B, Hardt WD: The role of microbiota in infectious disease. Trends Microbiol 2008, 16:107-114.

7. Kaur T, Ganguly NK: Modulation of gut physiology through enteric toxins. Mol Cell Biochem 2003, 253:15-19.

8. Heermann R, Fuchs TM: Comparative analysis of the Photorhabdus luminescens and the Yersinia enterocolitica genomes: uncovering candidate genes involved in insect pathogenicity. BMC Genomics 2008, 9:40.

9. Vallet-Gely I, Lemaitre B, Boccard F: Bacterial strategies to overcome insect defenses. Nat Rev Microbiol 2008, 6:302-313.

10. Gonzalez MR, Bischofberger M, Pernot L, Goot FG van der, Frêche B: Bacterial pore-forming toxins: the (w)hole story? Cell Mol Life Sci 2008 65:493-507.

11. Uzzau S, Fasano A: Cross-talk between enteric pathogens and the intestine. Cell Microbiol 2000, 2:83-89.

12. Schnepf HE, Crickmore N, Van Rie J, Lereclus D, Baum J, Feitelson J, Zeigler DR, Dean DH: Bacillus thuringiensis and its pesticidal crystal proteins. Microbiol Mol Biol Rev 1998, 62:775-806

13. Gill SS, Cowles EA, Pietrantonio PV: The mode of action of Bacillus thuringiensis endotoxins. Annu Rev Entomol 1992, 37:615-636.

14. Knowles BH: Mechanism of action of Bacillus thuringiensis insecticidal delta-endotoxins. Adv Insect Physiol 1994, 24:275-308.

15. Pigott CR, Ellar DJ: Role of receptors in Bacillus thuringiensis crystal toxin activity. Microbiol Mol Biol R 2007, 71:255-281.

16. Fast $P G$, Angus TA: Effects of parasporal inclusions of Bacillus thuringiensis var. sotto Ishiwata on the permeability of the gut wall of Bombyx mori (Linnaeus) larvae. J Invertebr Pathol 1965, 20:29-32.

17. Angus TA: A bacterial toxin paralysing silkworm larvae. Nature 1954 173:545-546.

18. Tabashnik BE, Liu YB, Dennehy TJ, Sims MA, Sisterson MS, Biggs RW, Carrière $Y$ : Inheritance of resistance to Bt toxin CrylAc in a field-derived strain of pink bollworm (Lepidoptera: Gelechiidae). J Econ Entomol 2002, 95:1018-1026.

19. Sutherland PW, Harris MO, Markwick NP: Effects of starvation and the Bacillus thuringiensis endotoxin CrylAc on the midgut cells, feeding behavior, and growth of lightbrown apple moth larvae. Ann Entomol Soc Am 2003, 96:250-264

20. Johnson DE, Freedman B: Toxicity of Bacillus thuringiensis Spo $\mathrm{Cr}^{+}$ mutants for the European Corn Borer Ostrinia nubilalis. Appl Environ Microbiol 1981, 42:385-387.

21. Aronson Al, Beckman W, Dunn PE: Bacillus thuringiensis and related insect pathogens. Microbiol Rev 1986, 50:1-24.

22. Johnson DE, Oppert B, McGaughey WH: Spore coat protein synergizes Bacillus thuringiensis crystal toxicity for the indianmeal moth. Curr Microbiol 1998, 36:278-282.

23. Toumanoff C, Vago C: Histopathological study of the silkworm with Bacillus cereus alesti. Ann Inst Pasteur 1953, 84:376-385

24. Heimpel AM: Investigations of the mode of action of strains of Bacillus cereus Fr. and Fr. pathogenic for the Larch sawfly, Pristiphora erichsonii (HTG). Can J Microbiol 1955, 33:311-326.

25. Nishitsutsuji-Uwo J, Endo Y: Mode of action of Bacillus thuringiensis $\delta$ enodotoxn: Relative roles of spores and crystals in toxicity to Pieris, Lymantria, and Ephestia larvae. Appl Entomol Zool 1980, 15:416-424.

26. Bizzarri MF, Bishop AH: The ecology of Bacillus thuringiensis on the phylloplane: Colonization from soil, plasmid transfer, and interaction with larvae of Pieris brassicae. Microb Ecol 2008, 104:60-69.

27. Schnepf HE, Whiteley HR: Cloning and expression of the Bacillus thuringiensis crystal protein gene in Escherichia coli. Proc Natl Acad Sci USA 1981, 78:2893-2897.

28. Cerstiaens A, Verleyen P, Van Rie J, Van Kerkhove E, Schwartz J-L, Laprade $\mathrm{R}$, De Loof A, Schoofs L: Effect of Bacillus thuringiensis Cry1 toxins in tnsect hemolymph and their neurotoxicity in brain cells of Lymantria dispar. Appl Environ Microbiol 2001, 67:3923-3927.

29. Shelton AM, Zhao JZ, Roush RT: Economic, ecological, food safety, and social consequences of the deployment of Bt transgenic plants. Annu Rev Entomol 2002, 47:845-881

30. Broderick NA, Raffa KF, Handelsman J: Midgut bacteria required for Bacillus thuringiensis insecticidal activity. Proc Natl Acad Sci USA 2006, 103:15196-15199

31. Broderick NA, Robinson CJ, McMahon MD, Holt J, Handelsman J, Raffa KF: Contributions of gut bacteria to Bacillus thuringiensis-induced mortality vary across a range of Lepidoptera. BMC Biology 2009, 7:11.

32. Ryu JH, Kim SH, Lee HY, Bai JY, Nam YD, Bae JW, Lee DG, Shin SC, Ha EM, Lee WJ: Innate immune homeostasis by the homeobox gene caudal and commensal-gut mutualism in Drosophila. Science 2008 319:777-782.

33. Kelly D, Conway S, Aminov R: Commensal gut bacteria: mechanisms of immune modulation. Trends Immunol 2005, 26:326-333.

34. Macpherson AJ, Harris NL: Interactions between commensal intestinal bacteria and the immune system. Nat Rev Immunol 2004, 4:478-485.

35. Pédron T, Sansonetti P: Commensals, bacterial pathogens and intestinal inflammation: an intriguing ménage à trois. Cell Host Microbe 2008, 3:344-347.

36. Buchon N, Broderick NA, Chakrabarti S, Lemaitre B: Invasive and indigenous microbiota impact intestinal stem cell activity through multiple pathways in Drosophila. Genes Dev 2009, 23:2333-2344.

37. Nenci A, Becker C, Wullaert A, Gareus R, van Loo G, Danese S, Huth M, Nikolaev A, Neufert C, Madison B, et al:: Epithelial NEMO links innate immunity to chronic intestinal inflammation. Nature 2007, 446:557-561.

38. Bates JM, Akerlund J, Mittge E, Guillemin K: Intestinal alkaline phosphatase detoxifies lipopolysaccharide and prevents inflammation in zebrafish in response to the gut microbiota. Cell Host Microbe 2007, 2:371-382.

39. Maillet F, Bischoff $V$, Vignal C, Hoffmann J, Royet J: The Drosophila peptidoglycan recognition protein PGRP-LF blocks PGRP-LC and IMD/ JNK pathway activation. Cell Host Microbe 2008, 3:293-303.

40. Dubovskiy IM, Martemyanov V, Vorontsova Y, Rantala M, Gryzanova E, Glupov W: Effect of bacterial infection on antioxidant activity and lipid peroxidation in the midgut of Galleria mellonella L. larvae (Lepidoptera, Pyralidae). Comp Biochem Physiol C Toxicol Pharmacol 2008, 148:1-5.

41. Dubovskiy IM, Krukova NA, Glupov V: Phagocytic activity and encapsulation rate of Galleria mellonella larval haemocytes during bacterial infection by Bacillus thuringiensis. J Invertebr Pathol 2008, 98:360-362.

42. Ericsson JD, Janmaat $A F$, Lowenberger $C$, Myers JH: Is decreased generalized immunity a cost of Bt resistance in cabbage loopers Trichoplusia ni? J Invertebr Pathol 2009, 100:61-67.

43. Gillespie JP, Kanost MR, Trenczek TE: Biological mediators of insect immunity. Annu Rev Entomol 1997, 42:611-643.

44. Lavine MD, Strand MR: Insect hemocytes and their role in immunity. Insect Biochem Mol Biol 2002, 32:1295-1309.

45. Cloud-Hansen KA, Peterson SB, Stabb EV, Goldman WE, McFall-Ngai SS, Handelsman J: Breaching the great wall: peptidoglycan and microbial interactions. Nat Rev Microbiol 2006, 4:710-716.

46. Kang D, Liu G, Lundström A, Gelius E, Steiner H: A peptidoglycan recognition protein in innate immunity conserved from insects to humans. Proc Natl Acad Sci USA 1998, 95:10078-10082.

47. McDonald C, Inohara N, Nuñez G: Peptidoglycan signaling in innate immunity and inflammatory disease. J Biol Chem 2005, 280:20177-20180

48. Alexopoulou L, Kontoyiannis D: Contribution of microbial-associated molecules in innate mucosal responses. Cell Mol Life Sci 2005, 62:1349-1358

49. Bao Y, Yamano Y, Morishima I: Induction of hemolin gene expression by bacterial cell wall components in eri-silkworm, Samia cynthia ricini. Comp Biochem Physiol B, Biochem Mol Biol 2007, 146:147-151.

50. Kaneko T, Goldman WE, Mellroth P, Steiner H, Fukase K, Kusumoto S, Harley W, Fox A, Golenbock D, Silverman N: Monomeric and polymeric Gram-negative peptidoglycan but not purified LPS stimulate the Drosophila IMD pathway. Immunity 2004, 20:637-649.

51. Noverr MC, Huffnagle GB: Does the microbiota regulate immune responses outside the gut? Trends Microbiol 2004, 12:562-568. 
52. Leaphart $\mathrm{CL}$, Tepas JJ: The gut is a motor of organ system dysfunction. Surgery 2007, 141:563-569.

53. Wells CL, Hess DJ, Erlandsen SL: Impact of the indigenous flora in animal models of shock and sepsis. Shock 2004, 22:562-568.

54. Nieuwenhuijzen GA, Deitch EA, Goris RJ: The relationship between gutderived bacteria and the development of the multiple organ dysfunction syndrome. J Anat 1996, 189:537-548.

55. Billiar TR, Maddaus MA, West MA, Curran RD, Wells CA, Simmons RL: Intestinal gram-negative bacterial overgrowth in vivo augments the in vitro response of Kupffer cells to endotoxin. Ann Surg 1988, 208:532-540.

56. Rozenfeld RA, Liu X, DePlaen I, Hsueh W: Role of gut flora on intestinal group II phospholipase A2 activity and intestinal injury in shock. Am J Physiol Gastrointest Liver Physiol 2001, 281:G957-963.

57. Shanmugam M, Sethupathi P, Rhee KJ, Yong S, Knight KL: Bacterialinduced inflammation in germ-free rabbit appendix. Inflamm Bowel Dis 2005, 11:992-996.

58. Freitak D, Wheat CW, Heckel DG, Vogel H: Immune system responses and fitness costs associated with consumption of bacteria in larvae of Trichoplusia ni. BMC Biol 2007, 5:56.

59. Cook JA: Eicosanoids. Crit Care Med 2005, 33:S488-491.

60. Stanley DW: Prostaglandins and other eicosanoids in insects: biological significance. Annu Rev Entomol 2006, 51:25-44.

61. Stanley-Samuelson DW, Jensen E, Nickerson KW, Tiebel K, Ogg CL, Howard RW: Insect immune response to bacterial infection is mediated by eicosanoids. Proc Natl Acad Sci USA 1991, 88:1064-1068.

62. Stanley DW, Miller JS: Eicosanoid actions in insect cellular immune functions. Entomol Exp App/ 2006, 119:1-13.

63. Gadelhak GG, Pedibhotla VK, Stanley-Samuelson DW: Eicosanoid biosynthesis by hemocytes from the tobacco hornworm, Manduca sexta. Insect Biochem Molec 1995, 25:743-749.

64. Tunaz H, Park Y, Buyukguzel K, Bedick JC, Nor Aliza AR, Stanley DW: Eicosanoids in insect immunity: bacterial infection stimulates hemocytic phospholipase A2 activity in tobacco hornworms. Arch Insect Biochem Physio/ 2003, 52:1-6.

65. Stanley D: The non-venom insect phospholipases A2. Biochim Biophys Acta 2006, 1761:1383-1390.

66. Pasquale TR, Tan JS: Nonantimicrobial effects of antibacterial agents. Clin Infect Dis 2005, 40:127-135.

67. Tauber SC, Nau R: Immunomodulatory properties of antibiotics. Curr Mol Pharmacol 2008, 1:68-79.

68. Bergin D, Reeves EP, Renwick J, Wientjes FB, Kavanagh K: Superoxide production in Galleria mellonella hemocytes: identification of proteins homologous to the NADPH oxidase complex of human neutrophils. Infect Immun 2005, 73:4161-4170.

69. Nappi AJ, Vass E: Cytotoxic reactions associated with insect immunity. Adv Exp Med Biol 2001, 484:329-348.

70. Shrestha S, Kim Y: Eicosanoids mediate prophenoloxidase release from oenocytoids in the beet armyworm Spodoptera exigua. Insect Biochem Mol Biol 2008, 38:99-112.

71. Marmaras VJ, Lampropoulou M: Regulators and signalling in insect haemocyte immunity. Cell Signal 2009, 21:186-195.

72. Munford RS: Severe sepsis and septic shock: the role of gram-negative bacteremia. Annu Rev Pathol 2006, 1:467-496.

73. Berger MM, Chioléro RL: Antioxidant supplementation in sepsis and systemic inflammatory response syndrome. Crit Care Med 2007 35:S584-590.

74. Uozumi N, Kita Y, Shimizu T: Modulation of lipid and protein mediators of inflammation by cytosolic phospholipase A2. J Immunol 2008, 181:3558-3566

75. Serhan C, Chiang N, Van Dyke T: Resolving inflammation: dual antiinflammatory and pro-resolution lipid mediators. Nat Rev Immunol 2008, 8:349-361.

76. Marcus AJ: The eicosanoids in biology and medicine. J Lipid Res 1984, 25:1511-1516

77. Bochud PY, Calandra T: Pathogenesis of sepsis: new concepts and implications for future treatment. BMJ 2003, 326:262-266.

78. Sibley CD, Duan K, Fischer C, Parkins MD, Storey DG, Rabin HR, Surette MG: Discerning the complexity of community interactions using a Drosophila model of polymicrobial infections. PLOS Pathog 2008, 4:e1000184
79. Broderick NA, Goodman RM, Raffa KF, Handelsman J: Synergy between zwittermicin A and Bacillus thuringiensis subsp kurstaki against gypsy moth (Lepidoptera: Lymantriidae). Environ Entomol 2000, 29:101-107.

80. Broderick NA, Raffa KF, Goodman RM, Handelsman J: Census of the bacterial community of the gypsy moth larval midgut by using culturing and culture-independent methods. Appl Environ Microbiol 2004, 70:293-300

81. Peterson SB, Dunn AK, Klimowicz AK, Handelsman J: Peptidoglycan from Bacillus cereus mediates commensalism with rhizosphere bacteria from the Cytophaga-Flavobacterium group. Appl Environ Microbiol 2006 72:5421-5427.

82. SAS Institute: SAS user's guide: statistics, version 9.1.3. Cary, NC 2006.

doi: $10.1186 / 1471-2180-10-129$

Cite this article as: Broderick et al., Chemical modulators of the innate immune response alter gypsy moth larval susceptibility to Bacillus thuringiensis BMC Microbiology 2010, 10:129

\section{Submit your next manuscript to BioMed Centra and take full advantage of:}

- Convenient online submission

- Thorough peer review

- No space constraints or color figure charges

- Immediate publication on acceptance

- Inclusion in PubMed, CAS, Scopus and Google Scholar

- Research which is freely available for redistribution

Submit your manuscript at www.biomedcentral.com/submit
C Biomed Central 